\title{
Improvement Cycle for Yield Ability of Crop Variety
}

\author{
Peizhan Tian \\ Centre of Germplasm Introduction and Crop Breeding of Jilin Province, Changchun, China \\ Email: peizhantian@163.com
}

Received 27 November 2015; accepted 11 December 2015; published 16 December 2015

Copyright (C) 2015 by author and OALib.

This work is licensed under the Creative Commons Attribution International License (CC BY). http://creativecommons.org/licenses/by/4.0/

(c) (i) Open Access

\begin{abstract}
Data on historical evolution of different crop cultivars in seventy years were further analyzed and big and small cycle of improvement of yield ability, alternating cycle improvement among number of ear per unit area, seed weight per ear, light absorption coefficient in community (or plant type), was first found. Each of big cycle was forty years. First big cycle from 1940 to late 1970, cross breeding was conducted on basis of arrangement and evaluation of local variety under situation of maintaining original and no improved plant type characteristics. The second big cycle since late seventies in twenty century on the basis of first improvement of plant type was started and underwent forty years. At present this big cycle was about ended. Third big cycle on basis of second plant type improvement should be forty years from 2020 to 2059. There were four small cycles in a big cycle, each of small cycle should be about decade. In each of four small cycles number of ear (or number of plant) and seed weight per ear should be alternatively or together heightened. In improvement of most ear type variety change of plant type were very obvious, but in biggest ear type breeding not obvious and in middle type breeding gradually obvious. On basis of cycle phenomenon and tree types of yield ability improvement author point out that breeding target of tree yield ability types, most ear type, biggest ear type and middle type, should be persisted, three parent combination ways, most ear $\times$ most ear, biggest ear $\times$ biggest ear and most ear $\times$ biggest ear should be persisted. Especially, selection for two extreme types should be first accomplished enhancing and development of middle type could be guided.
\end{abstract}

\section{Keywords}

Improvement Cycle, Yield Ability, Crop Variety

Subject Areas: Agricultural Science

\section{Introduction}

Many characters were changed in process of breeding. For certain region if ecological adaptability characters 
were scientifically and rationally determined and could be maintained over longer period, main object of breeding was enhancing yield ability of varieties. Main ways enhancing yield ability were increasing ear number (or plant number), seed weight per ear, and improving plant type. What were changes of several high-yielding factors in variety evolution? What were relationships among them? What was importance of relationship among they? Scholars all knew that these yield factors can enhance yield ability of a new variety, but study on reality relationship among they, for example study on improvement cycle for yield ability, had not been reported.

\section{Materials and Methods}

This paper was basis on data of mainly extensive cultivars from 1940 to 2010 in middle region of Jilin, China. Introduced from tables 15 - 28 in my works, "Philosophical Principle Increasing Crop Yield" [1] and "Annals of Crop Variety of Jilin Province” [2]. Averages of 7 - 9 cultivars in each years from 1940 to 2010 and percentages compared with above years were computed. Data in 2010 were mainly from major commercial cultivars in 2015 that were recommended by Agricultural Committee of Jilin Province. Characters inspected were general yield, highest yield (yield ability), suitable planting density, harvest ear (or plant), number seed weight per ear (or per plant).

\section{Study Results and Analysis}

\subsection{Improvement Cycle for Yield Ability and Its Difference among Crops}

Data on historical evolution of different crop cultivars showed that contradiction and its movement among seed yield factors of crop community, alternating cycle improvement among number of ear per unit area, seed weight per ear, light absorption coefficient in community (or plant type), in seventy years (Table 1). For example corn, in first big breeding cycle, forty years from forties to seventies in twenty century, cross breeding was conducted on basis of arrangement and evaluation of local variety under situation of maintaining original and no improved plant type characteristics, number of ear (or number of plant) and seed weight per ear were improved. Generally speaking, number of ear (number of plant) was first heightened, second seed weight per ear, third and fourth number of ear (number of plant) and seed weight per ear were alternatively or together heightened. Such alternating time, small cycle was generally decade. First big cycle in that seed yield factors were improved under situation maintaining original plant type characteristics was ended until late seventies in twenty century, and it underwent nearly forty years. At end planting density of corn was 4.56 ten thousand more than $41 \%$ of 3.23 ten thousand at beginning. In first big cycle effect of increasing yield of self regulation of plant type could not be neglected due to applying large fertilizer leading to increasing planting density.

Second big cycle since late seventies in twenty century on the basis of first improvement of plant type was started and underwent nearly forty years, It included four small cycles and in each of four small cycle number of ear, seed weight per ear, also were increased alternatively or together. At present this big cycle was about ended, corn planting density was 6.1 ten thousand, more than 33\% of 4.56 ten thousand at end of first big cycle. Yield ability of maize was reached $15,950 \mathrm{~kg} / \mathrm{hm}^{2}$, was 5.76 times in 1940 . Seed weight per ear of corn increased two times from 1940 to 2010, other crops were all smaller one time. This result indicated that two variety types most ear type and biggest ear type must be simultaneously paid attention to and done best. Present corm cultivars contained germplasm of variety of two extreme type.

Other crops were not as good as corn, number of ear of rice was obviously increased in first plant type improvement, but second was not conducted, enhancing yield ability almost depend on increasing seed weight per ear. Though Tong 35 etc varieties of bigger ear type [3], and varieties of more ear type Tongxi103, Fengyou 301 etc were bred, but breed tide of the two types were not formed. Plant type breeding of soybean was not almost conducted, and was in middle type breeding from beginning to end [4], and enhancing yield ability almost depend on increasing seed weight per plant. Though Jikedou1 a dense planting and more stem type variety, Pingandou 8 a thin planting and most stem variety, Ping-an 1020 high seed weight per plant and thin planting type [5] [6] variety were bred, but could not be persisted and widened, breeding of the two extreme types that keep place with middle type breeding was not set up. Yield ability of rice and soybean in 2010 was separately 2.58, 1.48 times in 1940. For sorghum, same hybrid vigor utilization crop with maize, smaller increasing range of number of ear in second big cycle and seed weight per ear in each of small cycle in two big cycle led to lower enhancing 2.9 times of yield ability. General, breeding of two extreme types was overlooked to lead to that breeding way was the more walking the more narrow, so bigger breeding advance could not obtained for rice soybean and 
Table 1. Alternating cycle improvement for yield ability characters of several crops in middle area in Jilin Province of China, in 1940-2010.

\begin{tabular}{|c|c|c|c|c|c|c|c|c|c|}
\hline \multirow{2}{*}{ Crop } & \multirow{2}{*}{$\begin{array}{c}\text { Big } \\
\text { cycle }\end{array}$} & \multirow{2}{*}{$\begin{array}{l}\text { Small } \\
\text { cycle } \\
\text { Years }\end{array}$} & \multicolumn{2}{|c|}{ Seed weight per ear ${ }^{*}$} & \multicolumn{2}{|c|}{ Planting density } & \multirow{2}{*}{$\begin{array}{c}\text { General } \\
\text { yield } \\
\mathrm{kg} / \mathrm{hm}^{2}\end{array}$} & \multicolumn{2}{|c|}{ Yield ability } \\
\hline & & & g & $\%$ & Ten thousand/hm² & $\%$ & & $\mathrm{~kg} / \mathrm{hm}^{2}$ & $\%$ \\
\hline \multirow{8}{*}{ Corn } & \multirow{4}{*}{ I } & 1940 & 85.7 & 100.0 & 3.23 & 100.0 & 1656 & 2768 & 100.0 \\
\hline & & 1950 & 127.5 & 148.8 & 3.08 & 95.4 & 2239 & 3928 & 141.9 \\
\hline & & 1960 & 180.2 & 141.3 & 3.78 & 122.7 & 4644 & 6813 & 173.4 \\
\hline & & 1970 & 168.5 & 93.5 & 4.56 & 120.6 & 5531 & 7687 & 112.8 \\
\hline & \multirow{4}{*}{ II } & 1980 & 213.8 & 126.9 & 4.59 & 100.7 & 8519 & 9813 & 127.7 \\
\hline & & 1990 & 232.8 & 108.9 & 4.94 & 107.6 & 9878 & 11,500 & 117.2 \\
\hline & & 2000 & 260.9 & 111.7 & 5.55 & 112.3 & 10,638 & 14,478 & 125.9 \\
\hline & & 2010 & 261.5 & 100.2 & 6.10 & 109.9 & 11,665 & 15,950 & 110.2 \\
\hline \multirow{8}{*}{ Rice } & \multirow{4}{*}{ I } & 1940 & 2.80 & 100.0 & 161.3 & 100.0 & 3506 & 4517 & 100.0 \\
\hline & & 1950 & 2.66 & 95.0 & 213.5 & 132.4 & 3666 & 5680 & 125.7 \\
\hline & & 1960 & 2.78 & 104.5 & 256.9 & 120.3 & 5500 & 7143 & 125.8 \\
\hline & & 1970 & 1.98 & 71.2 & 381.3 & 148.4 & 6480 & 7550 & 116.5 \\
\hline & \multirow{4}{*}{ II } & 1980 & 2.04 & 103.0 & 382.3 & 100.3 & 6830 & 7800 & 103.3 \\
\hline & & 1990 & 2.78 & 136.3 & 368.7 & 96.6 & 8285 & 10,250 & 131.4 \\
\hline & & 2000 & 2.91 & 104.7 & 378.0 & 102.5 & 8479 & 11,000 & 107.3 \\
\hline & & 2010 & 3.17 & 108.9 & 367.0 & 97.1 & 8750 & 11,663 & 106.0 \\
\hline \multirow{8}{*}{ Soybean } & \multirow{4}{*}{ I } & 1940 & 10.83 & 100.0 & 23.5 & 100.0 & 1657 & 2546 & 100.0 \\
\hline & & 1950 & 11.43 & 105.5 & 23.3 & 99.1 & 1781 & 2663 & 104.6 \\
\hline & & 1960 & 13.16 & 115.1 & 20.9 & 89.7 & 2019 & 2750 & 103.3 \\
\hline & & 1970 & 14.00 & 106.4 & 21.7 & 103.8 & 2268 & 2907 & 105.7 \\
\hline & \multirow{4}{*}{ II } & 1980 & 16.28 & 116.3 & 20.7 & 95.2 & 2550 & 3361 & 115.6 \\
\hline & & 1990 & 18.29 & 112.3 & 19.9 & 96.6 & 2744 & 3639 & 108.3 \\
\hline & & 2000 & 18.46 & 100.9 & 20.2 & 101.3 & 2775 & 3720 & 102.2 \\
\hline & & 2010 & 18.17 & 98.4 & 20.8 & 103.2 & 3014 & 3780 & 101.6 \\
\hline \multirow{8}{*}{ Sorghum } & \multirow{4}{*}{ I } & 1940 & 61.9 & 100.0 & 6.07 & 100.0 & 1675 & 3760 & 100.0 \\
\hline & & 1950 & 62.2 & 100.5 & 6.15 & 101.3 & 1833 & 3825 & 101.7 \\
\hline & & 1960 & 66.1 & 106.2 & 6.67 & 108.5 & 2483 & 4408 & 115.2 \\
\hline & & 1970 & 64.5 & 97.50 & 9.18 & 137.6 & 4538 & 5925 & 134.4 \\
\hline & \multirow{4}{*}{ II } & 1980 & 72.8 & 112.9 & 10.30 & 112.2 & 5943 & 7500 & 126.6 \\
\hline & & 1990 & 84.1 & 115.5 & 11.10 & 107.8 & 7575 & 9338 & 124.5 \\
\hline & & 2000 & 95.9 & 114.0 & 10.75 & 96.8 & 8418 & 10,312 & 110.4 \\
\hline & & 2010 & 96.7 & 100.8 & 11.25 & 104.7 & 8938 & 10,875 & 105.5 \\
\hline
\end{tabular}

sorghum as maize as.

For successfully entering thirdly big cycle, second cycle of plant type breeding, the key should be finding breeding material that Light Absorption Coefficient in community should be further reduced and Leaf Area Index (LAI) should be largely enhanced. Besides contradiction between quality and yield (such as soybean), biological yield and economical coefficient, in yield ability characters should be resolved. In next big breeding cycle a lot of breeding material that have high economical coefficient [7] could be bred and used in breeding of each crop, this will have profound and lasting significance for enhancing breeding level.

In variety improvement of most ear type change of plant type were very obvious, and main reason was that due to improving plant type and reducing light absorption coefficient in community most obvious result was increasing plant density and Leaf Area Index (LAI), leading to increasing seed yield. New variety of more ear type was easily bred, such unilateral tide was also easily formed. But on basis of basic principle [8] of crop breeding, if plant type was not improved, seed weight per plant or per ear was only improved, seed yield ability of new variety could be also increased. There were such instance in practice for example big ear and high-yielding maize varieties and high-yielding soybean varieties with original plant type or high seed yield per plant.

\subsection{Basic Regularities of Crop Breeding}

Comparison of above several crops showed that when beginning of each big cycle, corn was on basis of plant type improvement, not only its planting density had bigger increase. but also seed weight per ear was the same, 
so yield ability was quickly enhanced. Therefore bellow regularities should be remembered well:

First, on eternal stability of diverse type of yield ability character of crop cultivars, cultivars having same yield ability could be divided into three big types, 1 ) dense planting-small ear type (or more ear type), 2) thin planting-big ear type (or big ear type), 3) middle type that included diversely small types. Future along with enhancing of yield ability of new cultivars, the three types will be eternally maintained.

Second, even though future varieties will be divided into above three types, variation range of seed yield factors of each of three types should be bigger and bigger, subsonic or small type more and more, along with increasing of yield ability of new cultivars, and it accorded with "the more evolutional biology, the more complicated biology type", natural law that said by Friedrich Von Engels in "Natural Dialectics", works.

Thirdly, contradiction and its movement forming by diverse variety types were internal power of development and enhancing of yield ability of cultivars. The bigger variation range of yield ability factors among varieties on basis of high yielding the more opportunity producing more middle type and two extreme types, and precondition of combination and enhancing of each of two extreme types was provided. There was only one extreme type and no else, probability of enhancing and developing self was also lost. Relationship between two extreme types was mutual development condition and complemented each other. So standpoint of only emphasizing one and neglecting another one for two extreme types was very wrong, and expected advance of variety yield ability could not be realized.

Fourth, most important guidance significance of above regularity in crop breeding was that breeding objective of three variety types (most ear type, biggest ear type and middle type) should be determined and persisted in improvement of yield ability of variety, and on basis of super $\times$ super of parent yield ability level three parent combination ways, most ear $\times$ most ear, biggest ear $\times$ biggest ear and most ear $\times$ biggest ear should be persisted. Especially, selection for two extreme types should be first accomplished, and enhancing and development of middle type could be guided.

Fifth, contradiction between plant type and plant density was certainly emerged in breeding of more ear type, only way solving this contradiction was improving plant type. Objective of improvement of plant type was reducing light absorption coefficient in community, enhancing Leaf Area Index and dry matter yield, economic yield. The key was obvious enhancing Leaf Area Index. Most valid way reducing light absorption coefficient was small and upstanding leaves, suitably short height of plant. So such ideal material of plant type breeding must be first obtained and used in breeding of plant type, but in breeding of bigger ear type, more change characters were leaf photosynthesis efficiency [9], leaf thickness and seed weight per ear, not obvious plant type, in breeding of middle type above characters had some changes.

\subsection{Forecast for Advance of Yield Ability of Crop Variety in Thirdly Big Cycle and Division of Yield Ability Factors of Different Type Varieties}

Advance in thirdly big cycle could be forecasted on basis of advance in late decades (Table 2) and was advance under the conditions that above regularities could be carried out, and influence of soil fertility factor on it not be considered. When thirdly big cycle was completed, Increase of yield ability in bigger range and further division of yield factor type among different varieties existed side by side. Yield ability of corn variety will be 22,000 $\mathrm{kg} / \mathrm{hm}^{2}$ enhancing 37.5\% (compared with second big cycle), range of density $4.2-10.0$ ten thousand $/ \mathrm{hm}^{2}$, range of seed weight per ear 244 - 523 g; rice 17,500, 45.8\%, 270 - 750, 2.3 - 6.5; winter wheat in north of China 16,000, 33.3\%, 300 - 1000, 1.6 - 5.3; soybean 7500, 25\%, 10 - 30, (stem number 10 - 75); 10 - 14 - 75 per plant; millet 12,000, 110\%, 60 - 110, 11 - 20; sorghum 17,000, 54.5\%, 8.0 - 20.0, 85 - 213.

Therefore beginning at present preparative of biggest ear type and most ear type materials should be done well. If not well, still only stressing one type these objectives should not be reached.

\section{Conclusion}

Big and small cycle phenomenon of crop breeding was first found; in big one plant type it was mainly improved; in small one, seed yield factors, number of ear per unit area and seed weight per ear were alternately or together improved. Change of plant type was obvious in breeding of more ear type, in breeding of bigger ear type not obvious, in breeding of middle type gradually obvious. Breeding objective of above three yield ability types should be determined and persisted in improvement of yield ability of variety, and on basis of super $\times$ super of parent yield ability level three parent combination ways, most ear $\times$ most ear, biggest ear $\times$ biggest ear and most 
Table 2. Breeding cycle of yield ability of several crops and historical evolution, present and future of several main characters of yield ability.

\begin{tabular}{|c|c|c|c|c|c|c|c|c|c|c|c|c|c|c|c|}
\hline \multirow[b]{2}{*}{$\begin{array}{l}\text { Cycle } \\
\text { and } \\
\text { years }\end{array}$} & \multirow[b]{2}{*}{ Crop } & \multicolumn{4}{|c|}{ Most ear type } & \multicolumn{4}{|c|}{ Middle type (Average) } & \multicolumn{4}{|c|}{ Biggest ear type } & \multirow[b]{2}{*}{$\begin{array}{l}\text { General } \\
\text { yield } \\
\mathrm{kg} / \mathrm{hm}^{2}\end{array}$} & \multirow[b]{2}{*}{$\begin{array}{l}\text { Yield } \\
\text { ability } \\
\mathrm{kg} / \mathrm{hm}^{2}\end{array}$} \\
\hline & & Density & $\begin{array}{l}\text { Number } \\
\text { of ear }\end{array}$ & $\begin{array}{c}\text { Seed } \\
\text { weight } \\
\text { per ear }\end{array}$ & $\begin{array}{l}\text { Plant } \\
\text { type }\end{array}$ & Density & $\begin{array}{c}\text { Number } \\
\text { of ear }\end{array}$ & $\begin{array}{c}\text { Seed } \\
\text { weight } \\
\text { per ear }\end{array}$ & $\begin{array}{l}\text { Plant } \\
\text { type }\end{array}$ & Density & $\begin{array}{l}\text { Number } \\
\text { of ear }\end{array}$ & $\begin{array}{c}\text { Seed } \\
\text { weight } \\
\text { per ear }\end{array}$ & $\begin{array}{l}\text { Plant } \\
\text { type }\end{array}$ & & \\
\hline \multirow{6}{*}{$\begin{array}{c}0 \\
1940 \\
\text { beginning }\end{array}$} & Corn & 4.2 & 4.0 & 70.0 & $\mathrm{O}$ & 3.4 & 3.2 & 87.5 & $\mathrm{O}$ & 2.9 & 2.7 & 104.0 & $\mathrm{O}$ & 1700 & 2800 \\
\hline & Rice & 40.0 & 200.0 & 2.5 & $\mathrm{O}$ & 30.0 & 140.0 & 3.6 & $\mathrm{O}$ & 25.0 & 110.0 & 4.5 & $\mathrm{O}$ & 3700 & 5000 \\
\hline & Wheat & 310.0 & 350.0 & 0.5 & $\mathrm{O}$ & 300.0 & 320.0 & 0.8 & $\mathrm{O}$ & 230.0 & 250.0 & 1.1 & $\mathrm{O}$ & 1600 & 2600 \\
\hline & Soybean & 30.0 & 30.0 & 8.7 & $\mathrm{O}$ & 22.0 & 22.0 & 11.8 & $\mathrm{O}$ & 15.0 & 15.0 & 17.3 & $\mathrm{O}$ & 1700 & 2600 \\
\hline & Millet & 60.0 & 60.0 & 3.8 & $\mathrm{O}$ & 55.0 & 55.0 & 4.2 & $\mathrm{O}$ & 50.0 & 50.0 & 4.6 & $\mathrm{O}$ & 1600 & 2300 \\
\hline & Sorghum & 7.5 & 7.5 & 51.0 & $\mathrm{O}$ & 6.2 & 6.2 & 61.2 & $\mathrm{O}$ & 5.0 & 5.0 & 76.0 & $\mathrm{O}$ & 1800 & 3800 \\
\hline \multirow{6}{*}{$\begin{array}{c}\text { I } \\
1940 \\
- \\
1970\end{array}$} & Corn & 5.1 & 5.0 & 150.0 & $\mathrm{O}$ & 4.6 & 4.5 & 167.0 & $\mathrm{O}$ & 4.1 & 4.0 & 187.5 & $\mathrm{O}$ & 5750 & 7500 \\
\hline & Rice & 60.0 & 480.0 & 1.6 & $\mathrm{O}$ & 50.0 & 375.0 & 2.0 & $\mathrm{O}$ & 40.0 & 320.0 & 2.4 & $\mathrm{O}$ & 6500 & 7500 \\
\hline & Wheat & 270.0 & 800.0 & 1.0 & $\mathrm{O}$ & 150.0 & 580.0 & 1.3 & $\mathrm{O}$ & 100.0 & 350.0 & 2.1 & $\mathrm{O}$ & 6500 & 7500 \\
\hline & Soybean & 30.0 & 30.0 & 10.0 & $\mathrm{O}$ & 21.0 & 21.0 & 14.2 & $\mathrm{O}$ & 14.5 & 14.5 & 20.7 & $\mathrm{O}$ & 2300 & 3000 \\
\hline & Millet & 80.0 & 80.0 & 5.9 & $\mathrm{O}$ & 70.0 & 70.0 & 6.7 & $\mathrm{O}$ & 60.0 & 60.0 & 7.8 & $\mathrm{O}$ & 3300 & 4700 \\
\hline & Sorghum & 10.0 & 10.0 & 60.0 & $\mathrm{O}$ & 9.0 & 9.0 & 67.0 & $\mathrm{O}$ & 8.0 & 8.0 & 75.0 & $\mathrm{O}$ & 4500 & 6000 \\
\hline \multirow{6}{*}{$\begin{array}{c}\text { II } \\
1980 \\
- \\
2010\end{array}$} & Corn & 8.0 & 7.5 & 213.0 & $\mathrm{C}$ & 5.2 & 5.0 & 320.0 & $\mathrm{HC}$ & 4.5 & 4.5 & 355.0 & $\mathrm{O}$ & 11,000 & 16,000 \\
\hline & Rice & 70.0 & 580.0 & 2.1 & $\mathrm{C}$ & 55.0 & 450.0 & 2.7 & $\mathrm{HU}$ & 50.0 & 300.0 & 4.0 & $\mathrm{O}$ & 8700 & 12,000 \\
\hline & Wheat & 200.0 & 850.0 & 1.4 & $\mathrm{C}$ & 150.0 & 600.0 & 2.0 & $\mathrm{HU}$ & 75.0 & 300.0 & 4.0 & $\mathrm{O}$ & 8600 & 12,000 \\
\hline & Soybean & 10.0 & $55.0^{*}$ & 11.0 & $\mathrm{~S}$ & 20.0 & 20.0 & 30.0 & $\mathrm{O}$ & 10.0 & 10.0 & 60.0 & $\mathrm{O}$ & 3000 & 6000 \\
\hline & Millet & 80.0 & 80.0 & 7.1 & CD & 70.0 & 70.0 & 8.1 & $\mathrm{O}$ & 60.0 & 60.0 & 9.5 & $\mathrm{O}$ & 4500 & 5700 \\
\hline & Sorghum & 15.0 & 15.0 & 73.3 & CD & 11.5 & 11.5 & 96.0 & $\mathrm{O}$ & 8.0 & 8.0 & 137.5 & $\mathrm{O}$ & 8500 & 11,000 \\
\hline \multirow{6}{*}{$\begin{array}{c}\text { III } \\
2020 \\
- \\
2050\end{array}$} & Corn & 10.0 & 9.0 & 244.0 & US & 6.5 & 6.3 & 349.2 & $\mathrm{C}$ & 4.2 & 4.2 & 523.8 & $\mathrm{O}, \mathrm{HC}$ & 16,000 & 22,000 \\
\hline & Rice & 60.0 & 750.0 & 2.3 & US & 30.0 & 500.0 & 3.5 & $\mathrm{HU}$ & 15.0 & 270.0 & 6.5 & $\mathrm{O}, \mathrm{HC}$ & 13,000 & 17,500 \\
\hline & Wheat & 200.0 & 1000.0 & 1.6 & US & 150.0 & 650.0 & 2.5 & HU & 70.0 & 300.0 & 5.3 & $\mathrm{O}, \mathrm{HC}$ & 12,000 & 16,000 \\
\hline & Soybean & $13-30$ & $75.0^{*}$ & $10.0-13.6$ & US & 20.0 & 20.0 & 37.5 & $\mathrm{M}$ & 10.0 & 10.0 & 75.0 & $\mathrm{O}, \mathrm{HC}$ & 4500 & 7500 \\
\hline & Millet & 110.0 & 110.0 & 11.0 & US & 80.0 & 80.0 & 15.0 & CD & 60.0 & 60.0 & 20.0 & $\mathrm{O}, \mathrm{HC}$ & 8500 & 12,000 \\
\hline & Sorghum & 20.0 & 20.0 & 85.0 & US & 14.0 & 14.0 & 121.0 & CD & 8.0 & 8.0 & 213.0 & $\mathrm{O}, \mathrm{HC}$ & 12,500 & 17,000 \\
\hline
\end{tabular}

Plant type: C: Compact, D: Dwarf, H: Half, M: Middle type, O: Original type, S: Small leaf, U: Upstanding leaf. Data marking “*” was number of efficient stem including main stem of more branch soybean cultivar. Data of wheat was from winter wheat in north of China.

ear $\times$ biggest ear should be persisted. Especially, selection for two extreme types should be first accomplished, and enhancing and development of middle type could be guided. Important theory basis and key breakthrough technique were provided for enhancing breeding level and from practical breeding to scientific breeding.

\section{References}

[1] Tian, P.Z. and Wang, G.S. (2011) Philosophical Principle Increasing Crop Yield. Science Publishing House, Changchun.

[2] Agricultural Academy of Jilin (1965) Annals of Crop Variety in Jilin Province. People Publishing House of Jilin, Changchun.

[3] Tian, P.Z. (2014) Theoretical Genetics and Breeding Science of Crops. Science \&Technique Publishing House of Jilin, Changchun.

[4] Wang, L.Z., Luo, G.T., et al. (2012) Setting up Cultivation Technology of over 6 ton/hm² Yield of Spring Soybean Variety Zhonghuang 35 in North of Xinjiang. Soybean Science, 31, 217-223.

[5] Li, G.F. (2004) Selecting and Extending of a Big Ear Variety of Corn, Tongyu 97. Scientific Experiment in Countryside, No. 8, 20.

[6] Tian, P.Z., et al. (2012) Changing Biological Characteristics of Common Soybean to Increase Yield VI. Breeding of High-Yielding Cultivars. Jilin Agricultural Science (Changchun, Jilin, China), 37, 10-13.

[7] Sun, H.B., et al. (2009) Study on Transformation Ability Character of Dry matter in Soybean. Soybean Science, 28, 233-238.

[8] Tian, P.Z. (2015) Basic Principle and Technique System of Crop Breeding. Open Access Library Journal, 2 , e2032.

[9] Wang, Y.P., et al. (2015) Analysis of Physiological Character and Genetics in Big Seed Material lgl of Rice. Paper Collection, Crop Association Society of China, Harbin, p. 55. 